\title{
Uveal melanoma: therapeutic consequences of doubling times and irradiation results; a review
}

\author{
W.A. Manschot ${ }^{1}$ \& R. van Strik $^{2}$ \\ From the Institutes of Pathology ${ }^{I}$ and Epidemiology and Biostatistics ${ }^{2}$, Erasmus University, Rotterdam, \\ The Netherlands
}

Accepted 24 September 1991

Key words: uveal melanoma, doubling times consequences, post-irradiation histopathology consequences

\begin{abstract}
Thirty-six of 39 published calculated doubling times (Td's) of uveal melanomas appeared to be longer than 60 days. Metastatic death occurs 35-40 Td's after dissemination. The shortest interval between dissemination and metastatic death in individual patients may, therefore, be calculated as $35 \times 60$ days $=6$ years; the interval may extend to 80 years. This suggests, that local therapy cannot influence the survival data within the first 7 post-therapeutic years, because almost all metastatic deaths within these 7 years are due to pretreatment dissemination. For that reason, the published comparative survival analyses after various therapies have within this period failed to show statistically significant death rates differences.

Microscopically viable melanoma tissue has been noted in 215 of 231 histopathologically studied irradiated uveal melanomas. Observed mitotic figures 4-6 years after irradiation indicate retained reproductive integrity. This constitutes a - by enucleation avoidable - incremental risk for post-irradiation exponential growth and dissemination. The risk cannot become statistically manifest before a $\geq 10$-year follow-up period. Retained, generally poor, visual acuity in a small percentage of patients cannot balance the incremental risk/benefit ratio of irradiation. A few, at present justifiable, indications for radiotherapy on uveal melanomas are enumerated.
\end{abstract}

\section{Introduction}

Management of choroidal melanomas is still controversial. Available data have not yet definitely established whether enucleation or irradiation is more effective in prolonging life. Other undecided significant issues are related to vision preservation and posttherapeutic quality of life. For these reasons, a multicentre-controlled Collaborative Ocular Melanoma Study (COMS) has been initiated at 32 clinical centres throughout the United States and Canada in 1986 [73]. The COMS includes 1) a trial for patients with medium choroidal melanomas which are assigned randomly to treatment by primary enucleation or by iodine-25 plaque irradiation; 2) a trial for patients with larger melanomas, assigned randomly to treatment by primary enucleation without or with preceding external beam irradiation, and 3) a prospective observational study for patients with small melanomas, treated according to preferences of the ophthalmologist and the patient. Each patient in the first two trials is scheduled for follow-up examination at least annually for 10 years or until death; data of the observational study will be reviewed after a 2 -year period, to determine the appropriateness of a randomized trial for patients with small melanomas.

The first results of cobalt- 60 plaque therapy on 
patients with uveal melanoma have been reported in 1959 [72]. For many years, radiotherapy received moderate attention, until it was postulated in 1978 [76], that approximately two-thirds of the fatalities after enucleation could be attributed to dissimination of tumour emboli at the time of enucleation. This publication stimulated interest in various types of conservative therapy for uveal melanomas. It also aroused fundamental controversies on the correctness of the postulate and its recommendation not to enucleate eyes with small melanomas [48] and on the justifiability of irradiation of uveal melanomas in general $[24,51,69,73)$. Brachytherapy on uveal melanomas is generally performed by means of applicators emitting gamma rays (cobalt-60, iodium-125) or beta rays (ruthenium-106). Teletherapy is applied by means of proton or helium ion charged particles.

Survival statistics after enucleation cover followup periods of 10-25 years and represent all affected individuals. The corrected mortality rates extend from $40-57 \%[36,48,76]$. Despite $15-20$-year irradiation experience in many centres, reported survival results after irradiation seldom have followup periods exceeding 5 years. Also, these reports often represent groups of patients selected according to varying criteria; this induces statistical selection artifacts, which cast doubt on their value. It is acknowledged [5] that the survival rate of irradiated patients has never been compared with that of properly matched groups of enucleated patients.

The purposes of this review are 1) to evaluate the statistical consequenses of 39 published calculated doubling times (Td's) of uveal melanomas for the relevance of the so far published results of radiotherapy; 2) to update a previously published table of 43 histopathologic reports on irradiated uveal melanomas [51] to a table of 231 reports; 3) to evaluate possible influence of irradiation on survival; 4) to summarize published post-irradiation visual function reports and 5) to formulate on this basis and objective answer to the fundamental question when irradiation of a uveal melanoma may be considered a justifiable, scientifically based treatment.

\section{Consequences of calculated doubling times}

Basic oncological principles like growth rate and doubling time $(\mathrm{Td})$ were introduced in the discussion on the therapy of uveal melanomas by us in $1980[48,49]$. It was then postulated - based on known Td's of skin melanomas - that Td's of uveal melanomas with a significant component of epitheloid cells might vary between 30 and 100 days, and Td's of spindle cell melanomas between 100 and 365 days. Since then, 39 calculated Td's of uveal melanomas have been published (Table 1). The first report [25] concerns $1 \mathrm{Td}$, calculated as being 17 days; this has remained the shortest uveal melanoma Td ever published. Two following reports [3, 29] concern 19 and 18 Td's respectively, which range from 22.6 to 540 days [3] and from 2 to 135 months [29]. Both papers stress the great limitations in accurate measurement of changes in intraocular tumour size. Finally [64], the Td has been calculated of an extremely rapidly growing melanoma in a diabetic patient, in which fundus photography and fluorescein angiography had been performed 29 and 16 months before the eye was enucleated because of a choroidal mass, which could

Table 1. Calculated doubling times of uveal melanomas.

\begin{tabular}{lclc}
\hline & Number & $\begin{array}{l}\text { Follow-up } \\
\text { (Months) }\end{array}$ & Doubling time \\
\hline Friberg et al. $(1983)^{25}$ & 1 & 2 & 17 days \\
Augsburger et al. $(1984)^{3}$ & 19 & $0.8-30$ & $23-540$ days \\
Gass $(1985)^{29}$ & 18 & $3-170$ & $2-135$ months \\
Sahel et al. $(1988)^{64}$ & 1 & 2 & 64 days \\
\hline
\end{tabular}

* Certain tumours with minimal growth were presumed to be naevi. 
not be detected on the pictures made previously. The Td of this rapidly growing melanoma is 64 days. Only 3 of the 39 calculated Td's are shorter than 60 days. This outcome warrants the acceptance, for practical therapeutic and prognostic considerations in individual patients, of a shortest possible Td of 60 days.

In 1956 Collins et al. [18] presented evidence, that death by metastasis occurs 35-40 Td's after dissemination. This postulate - which does not imply the assumption that all metastases grow exponentially from the first cell to clinical size, because Td represents a mean value - has never been contradicted by others $[27,11,47]$, who repeated and extended Collins' fundamental work. The shortest possible interval between dissemination and metastatic death for patients with a uveal melanoma may, therefore, be postulated as e.g. $35 \times 60$

Table 2. Histopathology of irradiated choroidal melanomas.

\begin{tabular}{|c|c|c|c|}
\hline & Number & $\begin{array}{l}\text { Tumour } \\
\text { necrosis }\end{array}$ & $\begin{array}{l}\text { Viable } \\
\text { tumour }\end{array}$ \\
\hline Char et al. (1977) $)^{\mathbf{a}^{12}}$ & 4 & 2 & 4 \\
\hline McFaul et al. $(1980)^{9^{57}}$ & 23 & 6 & 23 \\
\hline Zinn et al. $(1981)^{\mathrm{c}^{77}}$ & 1 & 1 & 1 \\
\hline Seddon et al. $(1983)^{666}$ & 3 & 3 & 3 \\
\hline Char et al. $(1983)^{\mathrm{d}^{13}}$ & 3 & 2 & 3 \\
\hline Albert $(1983)^{c^{2}}$ & 1 & 1 & 1 \\
\hline Gass $(1985)^{\mathrm{a}^{28}}$ & 5 & 5 & 4 \\
\hline Schmitt $(1985)^{\mathrm{e}^{65}}$ & 1 & 1 & 1 \\
\hline Ferry et al. $(1985)^{\mathrm{c}^{23}}$ & 1 & 1 & 1 \\
\hline Guthoff et al. $(1986)^{b^{33}}$ & 16 & $10 ?$ & 14 \\
\hline Hanssens $(1986)^{b^{35}}$ & 4 & 3 & 4 \\
\hline Goodman et al. (1986) & 1 & 1 & 1 \\
\hline Lommatzsch $(1986)^{b^{45}}$ & 60 & $8 ?$ & 56 \\
\hline Manschot $(1986)^{\mathrm{b}^{55,56}}$ & 3 & 2 & 2 \\
\hline Crawford $(1987)^{\mathrm{d}^{19}}$ & 27 & 26 & 26 \\
\hline Daicker $(1987)^{\mathrm{c}^{21}}$ & 1 & 1 & 1 \\
\hline Donders $(1987)^{c^{22}}$ & 1 & 1 & 1 \\
\hline Lee $(1987)^{\mathrm{a}, b^{42}}$ & 3 & 1 & 3 \\
\hline Kincaid et al. $(1988)^{c^{38}}$ & 5 & 5 & 5 \\
\hline Fuchs et al. $(1988)^{a, b 26}$ & 8 & 2 & 8 \\
\hline Lawton $(1989)^{c^{11}}$ & 1 & 1 & 1 \\
\hline \multirow[t]{2}{*}{ Shields et al. $(1990)^{\mathrm{a}, \mathrm{b}, \mathrm{f}, \mathrm{g}^{71}}$} & 59 & 59 & 52 \\
\hline & 231 & $142 ?$ & 215 \\
\hline
\end{tabular}

${ }^{\mathrm{a}}$ Cobalt- 60 irradiation; ${ }^{\mathrm{b}}$ Ruthenium-106 irradiation; ${ }^{\mathrm{c}}$ Proton beam irradiation; ' Helium-ion irradiation; ${ }^{\mathrm{e}}$ Strontium-90 irradiation; ${ }^{\mathrm{f}}$ Tridium-192 irradiation; ${ }^{\mathrm{g}}$ Iodine- 125 irradiation. days $=6.1$ years; the longest interval might at least be $40 \times 2$ years $=80$ years!

It appears accepted that metastases often tend to grow more rapidly than the primary tumour [58]. Published calculations of doubling times of uveal melanomas have all been based on the growth rate of primary tumours. The postulate on the growth rate of metastases of these primaries has for practical considerations been based on a shortest primary Td of 60 days (see above). The mean Td representing the great majority of all calculated Td's of uveal melanomas has been determined to be between 150 and 250 days. An assumed decrease of $50 \%$ in the $\mathrm{Td}$ of melanoma metastases relative to the $\mathrm{Td}$ of the primary tumour might result in a metastatic Td, which would nearly always be substantially longer than 60 days. The implicate is, that tumour-related death within at least 6 years after therapy must be due to dissemination, which occurred before therapy. A large, gradually decreasing proportion of metastatic deaths in the years following this 6-year period is also due to pretherapeutic metastases. This implies that with identical selection of patients no significant differences in survival rate can occur within the first 7-8 years after enucleation, various conservative therapies or observation only. This postulate has amply been confirmed by many advocates of irradiation, who reported absence of death rate differences already in 1986, in many reports during the 1987 International Meeting on Intraocular Tumors and in more recent reports $[1,5,8,10,32,67,69]$. Non-randomized, comparative survival analyses after respectively cobalt -60 plaque therapy vs enucleation and proton beam irradiation vs enucleation have already indicated that irradiation and primary enucleation are essentially equivalent in their effect on survival within 6-7 years after therapy $[8,67]$. A supposed immunological impact on metastatic death rate has never been proved [61].

\section{Histopathology of irradiated melanomas}

Table 2 illustrates that all types of radiotherapy fail to destroy all malignant cells in uveal melanomas: 215 of 231 published microscopic examinations 
(93\%) mentioned viable tumour cells, while $39 \%$ of the tumours did not show signs of necrosis. These 231 melanomas may not be fully representative for the several thousands of apparently successfully irradiated melanomas, but the table is nonetheless meaningful. The majority of these 231 eyes have probably not been enucleated because of tumour regrowth, but because of irradiation damage. In 2 series of respectively 26 and 27 eyes, 19 and 18 had been enucleated because of this damage and only 7 and 4 because of tumour regrowth [17, 19]. In a series of 59 eyes, 30 had been enucleated because of 'regrowth or failure of the tumor to decrease in size' - of which no further data were given -, 24 because of irradiation complications and 5 on patient request [70].

It is unclear whether the histological presence of apparent viable tumour cells demonstrate a failure of radiotherapy to sterilize all tumour stem cells. It is certain that irradiation can have a profound effect on the viability of uveal melanoma cells. This appears from a frequently encountered substantial and sometimes total post-irradiation tumour regression. It is to be appreciated, however, that regression of $50 \%$ or even $75 \%$ of the original tumour volume can only delay metastatic death for one or two Td's respectivally; it cannot prevent eventual death from metastases. Only total regression may save the life of the patient, if no metastases had been present before therapy.

Reports on 7 proton beam irradiated eyes revealed mitotic activity in all 7 melanomas $[21,38$, 41]. The time interval between irradiation and enucleation had been more than 4 years in 3 cases. Presence of mitotic figures in irradiated tumour tissue in the first years after irradiation does not prove retained reproductive integrity. It has been shown in vitro that, although irradiated cells were capable of passing several cell cycles, the clonogenic cells were sterile $[62,72]$. But mitoses in a tumour increasing in size and mitoses a number of years after irradiation are indicative for the presence of vital tumour stem cells. They indicate that irradiation not always destroys the reproductive integrity of all tumour stem cells as has been stated [14].

The 10 -year-old recommendation to prevent iatrogenic dissemination of melanoma cells during enucleation by means of two consecutive daily preenucleation doses of $400 \mathrm{rad}$ on the primary tumour, sufficient to kill $90 \%$ of the tumour cells, might still hold true $[48,59]$. Studies on pre-operatively irradiated human melanoma cells in tissue culture substantiate that irradiation indeed decreases the attachment, growth and viability of melanoma cells in these cultures, while microscopic examination indicated a reduced mitotic activity $[7,16,37,63]$. No beneficial effect of pre-enucleation irradiation could, however, be observed in terms of better survival after pre-enucleation irradiation as compared with control groups $[9,15,40]$. It appears that the mean or median follow-up periods have been 47,37 and 35 months respectively [9, $15,40]$. It has been explained above, that these periods are much too short to be of statistical relevance.

\section{Irradiation and survival}

It has also been explained that local therapy on uveal melanomas cannot influence significantly the survival of these patients within the first 7-8 posttherapeutic years. The chance of metastatic death within these years fully depends on the presence or absence of disseminated tumour cell emboli at the time of therapy.

Data on survival after conservative therapy on uveal melanomas need two basic requirements for comparable statistics: 1) 10-year or longer followup periods and 2) randomisation of all patients. The necessity of follow-up periods of at least 10 years has repeatedly been stressed by us [50-56]. This necessity has in the mean time been substantiated by calculated Td's of these tumours.

So far, only one institution has compared metastatic death rates after treatment by enucleation and by cobalt plaque therapy after a mean followup period of 10 years [28]. Metastatic death had occurred in $22 \%$ of the enucleated patients and in $57 \%$ of the irradiated ones; the median survival had respectively been more than 10 years and 3.8 years. Much criticism has been expressed on this report, but the most relevant argument against it has never been raised, viz. that 10 of 12 irradiated 
patients had died from metastasis within the first 5 post-irradiation years. This indicates that metastases had occurred prior to irradiation. It is disquieting that 6 years after this first 10-year follow-up report none of the other centres, which have applied radio-therapy for uveal melanomas more than 15 years, has so far published its 10 -year survival and functional results in all treated patients. Shorter follow-up periods cannot indicate survival advantages or disadvantages of irradiation therapy.

The frequent survival of melanoma cells after irradiation, as appears from Table 2 , can be explained by

1) a remarkable efficient repair system of melanoma cells, with a greater ability to repair sublethal and potentially lethal radiation damage than of most other tumour cells [33, 44, 73].

2) The often large portion of poorly oxygenated cells in melanomas demands high daily radiation fractions $[34,60]$.

3) In an individual patient, the radiotherapist cannot predict the reaction of the tumour and its surrounding tissue after an empirical radiation dose. We found absence of microscopic necrosis in a choroidal melanoma in a 31 -year-old female (lab. nr. 0.2175), 8 months after the last of 3 ruthenium doses, totalling $1556 \mathrm{~Gy}$, which had been applied in 3 consecutive years [55]. In contrast, the eye of a 65-year-old female (lab. nr. 0.2278 ), who had received 1377 Gy ruthenium in the same clinic, revealed 3 months later total necrosis of the melanoma and extensive retinal necrosis with vitreous haemorrhages [56]. There is no known safe margin between inadequate and excessive radiation doses for choroidal melanomas.

4) Current clinical methods of measurement of intraocular tumours do not provide data which correspond reliably to all measurements in the pathology laboratory [4]. It has been found that the correlation between ultrasonography and pathological measurement of tumour thickness was substantially greater than that between clinical and pathological estimates of tumour basal diameters [6]. The files of the Rotterdam University Pathological Institute contain 4 cases, in which margins of flat intrachoroidal melanoma extensions, which cannot be diagnosed clinically, reach more than $10 \mathrm{~mm}$ beyond the clinically detectable tumour prominence. These basal margins are essential for choosing the appropriate radiation applicator, which seldom covers more than a $2 \mathrm{~mm}$ broad area around this prominence [17]. This might partly explain, why virtually all clinically measurable post-irradiation regression of choroidal melanomas has been in thickness and not in basal size of the lesion [20]. It also explains that eyes with tumour regrowth develop the growth not so much in thickness but in horizontal lateral dimensions [71].

The histopathologic post-irradiation findings in uveal melanomas (Table 2) are a strong argument in favor of primary enucleation of these tumours. This argument has recently been enforced firmly by a 5-year follow-up report after helium ion therapy and by the already mentioned microscopic study on 59 uveal melanomas enucleated after plaque radiotherapy $[17,70,71]$. Standardized A-scan ultrasonography revealed that 5 year after helium ion therapy $72 \%$ of 164 melanomas had either increased in thickness or had decreased less than $50 \%$, while only $8 \%$ had shrunken more than $70 \%$ [17]. The microscopic study on 59 plaque irradiated melanomas showed unequivocal mitotic cells in $36 \%$ of the tumour residues [71]. It must be realized that exponential regrowth in such a large percentage of often non-sterilized melanoma residues incurs an incremental risk of metastatic death for irradiated patients after 8 years or more.

\section{Preservation of vision after irradiation}

Reports on retained visual acuity after irradiation indicate that the 'fight for sight' principle, which is the main argument in favour of radiotherapy on uveal melanomas loses much of its authenticity after follow-up periods of more than 5 years.

Table 3 presents published reports on retained visual function after radiotherapy. Various methods of reporting make comparison of data hardly possible. The most recent report noted that visual 
acuity decreased at least two lines in $84 \%$ of irradiated eyes [17]. It often declines steadily at a rate of approximately $10 \%$ per year [10]. About $10-15 \%$ of irradiated eyes retain a visual acuity of more than 0.1 after 5 years. Reported pinhole acuity has little practical value. However, even a minute acuity is better than the complete loss of vision after enucleation. Patients with small tumours relatively distant from the macular region and the optic nerve may have better results. In $59 \%$ of patients with a pre-treatment visual acuity of at least 0.4 , this acuity was retained, if the tumour was more than $3 \mathrm{~mm}$ from the central fovea and the optic nerve and if its height was less than $6 \mathrm{~mm}$. In contrast, this vision was preserved in only $16 \%$ of patients with melanomas within $3 \mathrm{~mm}$ of these structures and a height of more than $6 \mathrm{~mm}$.

\section{Conclusions}

Calculated doubling times of posterior uveal melanomas indicate that metastatic death within 6-7 years after diagnosis of the primary tumour nearly always originates from pre-diagnostic metastases and, therefore, is independant of any locally applied therapy on the primary uveal lesion. Difference in survival rates, observed within this period after various therapies, is almost certainly due to difference in selection of patients for treatment.

The presence of viable melanoma tissue in $93 \%$ of all microscopically studied irradiated melano- mas, in which mitotic figures have been observed even 4-6 years after proton beam irradiation and in $36 \%$ after plaque irradiation, suggests an incremental risk of metastatic death after 7-8 year postirradiation period.

Poor post-radiation visual acuity in the great majority of patients, does not balance the incremental risk of post-irradiation dissemination and metastatic death.

It is felt that this anticipated unfavourable riskbenefit ratio, which is not clearly manifest before follow-up periods of more than 10-year does not justify radiotherapy of uveal melanomas in centres, which do not participate in the COMS, on other patients than those with 1) small melanomas distant from the fovea and optic nerve, 2) a life expectancy of less than 6 years, 3) a melanoma in a single functioning eye and 4) patients who refuse enucleation.

Also for patients with small melanomas - which are unlikely to shed cell emboli before they have reached the $7 \mathrm{~mm}$ diameter stage [51] - the COMS will need a follow-up period of more than 10 years, before it can reach a definite conclusion concerning the justifiableness of as well observation as irradiation of these melanomas. Metastatic death in patients with small melanomas occurs markedly later than in patients with medium sized or large tumours.

Table 3. Preservation of vision after radiotherapy.

\begin{tabular}{|c|c|c|c|}
\hline & Number & Follow-up & Preservation of vision \\
\hline Augsburger et al. $(1986)^{5}$ & 97 & $67 \%>5 \mathrm{yrs}$ & $\begin{array}{l}\text { 'large proportion patients } \\
\text { will lose all useful vision' }\end{array}$ \\
\hline Seddon et al. $(1986)^{68}$ & $522^{*}$ & median: 19 months & $\begin{array}{l}35 \% \text { lost initial vision } \geq 0.1 \\
\text { in } 1.6 \text { years (pinhole) }\end{array}$ \\
\hline Gragoudas et al. $(1987)^{31}$ & $125^{*}$ & median: $5.4 \mathrm{yrs} 15 \%<2 \mathrm{yrs}$ & $42 \% \leq 0.1$ (pinhole) \\
\hline Linstadt et al. $(1988)^{43}$ & 186 & median: 26 months & $51 \%<0.1$ \\
\hline Lommatzsch et al. $(1988)^{46}$ & 309 & $\geq 5 \mathrm{yrs}$ & $13.7 \% \geq 0.3$ \\
\hline Brady et al. $(1988)^{10}$ & 178 & $\geq 5$ yrs & $\begin{array}{l}\text { percentage vision } \geq 0.1 \\
\text { declines } \pm 10 \% \text { per year }\end{array}$ \\
\hline Kindy-Degan et al. $(1989)^{39}$ & 284 & mean: 30 months & $12.3 \%>0.1$ \\
\hline
\end{tabular}

*Identical study population. 


\section{Acknowledgement}

The authors thank Professor B.H.P. van der WerfMessing, Ph.D, M.D., Rotterdam and A.H. Mulder, Ph.D., M.D., Rotterdam, for critically reading the manuscript and Professor W.R. Lee, M.D., Glasgow, for critically reading the manuscript and helping in its preparation.

\section{References}

1. Adams KS, Abrahamson DH, Elsworth RM, Haik BG, Bedford M, Packer S, Seddon J, Albert D, Polivogianis L. Cobalt plaque versus enucleation for uveal melanoma: comparison of survival rates. Brit J Ophthalmol 1988; 72: 494-7.

2. Albert DM. Proton beam treated ocular melanoma. Read before Eur Ophthalmopathol Soc Groningen, Netherlands, 1985.

3. Augsburger JJ, Gonder JR, Amsel J, Shields JA, Donoso LA. Growth rates and doubling times of posterior uveal melanomas. Ophthalmology 1984; 91: 1709-15.

4. Augsburger JJ, Gamel JW, Bailey RS, Donoso LA, Gonder JR, Shields JA. Accuracy of clinical estimates of tumor dimensions. Retina 1985; 5: 26-9.

5. Augsburger JJ, Gamel JW, Sardi VF, Greenberg RA, Shields JA, Brady LW. Enucleation vs cobalt plaque radiotherapy for malignant melanomas of the choroid and ciliary body. Arch Ophthalmol 1986; 104: 655-61.

6. Augsburger JJ, McNeary BT, von Below H, Gamel JW, Shields JA, Brady LW, Markoe AM. Regression of posterior uveal malignant melanomas after cobalt plaque therapy. Graefe's Arch Clin Exp Ophthalmol 1986; 224: 397-400.

7. Augsburger JJ, Eagle RC, Chiu M, Shields JA. The effect of pre-enucleation radiotherapy on mitotic activity of choroidal and ciliary body melanomas, Ophthalmology 1987; 94: 1627-30.

8. Augsburger JJ, Gamel JW, Lauritzen K, Brady LW. Cobalt-60 plaque radiotherapy vs enucleation for posterior uveal melanoma. Am J Ophthalmol 1990; 109: 585-92.

9. Bornfeld N, Huser U, Sauerwein W, Sack H. Präoperative Bestrahlung vor Enukleation bei malignen Melanom der Uvea. Klin Mbl Augenheilk 1989; 194: 252-60.

10. Brady LW, Markoe AM, Amendola BE, Karlson UL, Micaily B, Shields JA, Augsburger JJ. The treatment of primary intraocular malignancy. Int J Rad Oncol Biol Phys $1988 ; 15: 1355-61$.

11. Breur K. Growth rate and radiosensitivity of human tumours - I: growth rate of human tumours. Eur J Cancer 1966; 2: 157-71.

12. Char DH, Lonn LI, Margolis LW. Complications of cobalt plaque therapy of choroidal melanoma. Am J Ophthalmol 1977; 84: 536-41.
13. Char DH, Crawford JB, Castro JR, Woodruff KH. Failure of choroidal melanoma to respond to helium ion therapy. Arch Ophthalmol 1983; 101: 236-41.

14. Char DH. Therapeutic options in uveal melanoma. Am J Ophthalmol 1984; 98: 796-9.

15. Char DH, Phillips TL, Andejeski Y, Crawford JB, Kroll MA. Failure of preenucleation radiation to decrease uveal melanoma mortality. Am J Ophthalmol 1988; 106: 21-6.

16. Char DH, Huhta $\mathrm{K}$, Waldman F. DNA cell cycle studies in uveal melanoma. Am J Ophthalmol 1989; 107: 65-72.

17. Char DH, Castro JR, Kroll SM, Irvine AR, Quivey JM, Stone RD. Five-year follow-up of helium ion therapy for uveal melanoma. Arch Ophthalmol 1990; 108: 209-14.

18. Collins VP, Loeffler RK, Tivey H. Observations on growth rates of human tumors. Am J Roentgenol 1956; 76: 9881000 .

19. Crawford JB, Char DH. Histopathology of uveal melanomas treated with charged particle radiation. Ophthalmology 1987; 94: 639-43.

20. Cruess AF, Augsburger JJ, Shields JA, Brady LW, Markoe AM, Day JL. Regression of posterior uveal melanomas following cobalt-60 plaque radiotherapy. Ophthalmol 1984; 91: 1716-9.

21. Daicker B. Proton beam irradiated malignant melanoma of the ciliary body with metastases or seeding to the opposite sclera. Read before Eur Ophthalmopathol Soc Peebles, Scotland, 1987.

22. Donders PC. Proton-beam irradiated melanoma. Discussion after Daicker [21]. Europ Ophthalmopathol Soc Peebles, Scotland, 1987.

23. Ferry AP, Blair CJ, Gragoudas ES, Volk SC. Pathologic examination of ciliary body melanoma treated with proton beam irradiation. Arch Ophthalmol 1985; 103: 1849-53.

24. Fine SL. Do I take the eye out or leave it in? Arch Ophthalmol 1986; 104: 653-4.

25. Friberg TR, Fineberg E, McQuaig S. Extremely rapid growth of a primary choroidal melanoma. Arch Ophthalmol 1983; 101: 1375-7.

26. Fuchs U, Kivelä T, Tarkkanen A, Laatikainen L. Histopathology of enucleated intraocular melanomas irradiated with cobalt and ruthenium plaques. Acta Ophthalmol 1988; 66: 255-66.

27. Garland LH, Coulson W, Wollin E. The rate of growth and apparent duration of untreated primary bronchial carcinoma. Cancer 1963; 16: 694-707.

28. Gass JDM. Comparison of prognosis after enucleation vs cobalt 60 irradiation of melanomas. Arch Ophthalmol 1985; 103: 916-23.

29. Gass JDM. Comparison of uveal melanoma growth rates with mitotic index and mortality. Arch Ophthalmol 1985; 103: 924-31.

30. Goodman DF, Char DH, Crawford JB, Stone MD, Castro JR. Uveal melanoma necrosis after helium ion therapy. Am J Ophthalmol 1986; 101: 643-5.

31. Gragoudas ES, Seddon JM, Egan K, Glynn R, Munzenrider J, Austin-Seymour M, Goitein M, Verhey L, Urie M, 
Koehler A. Long-term results of proton beam irradiated uveal melanomas. Ophthalmology 1987; 94: 349-53.

32. Gragoudas ES, Seddon JM, Egan KM, Glynn RJ, Goitein M, Munzenrider J, Verhey L, Urie M, Koehler A. Metastasis from uveal melanoma after proton beam irradiation. Ophthalmology 1988; 95: 992-8.

33. Guthoff R, von Domarus D, Steinhorst U, Hallerman D. 10 Jahre Erfahrung mit der Ruthenium-106/Rhodium-106-Behandlung des malignen Melanoms der Aderhaut - Bericht über 264 bestrahlte Tumoren. Klin Mbl Augenheilk 1986; 188: 576-83

34. Habeshaw T, Wheldon TE. Malignant melanoma: the role of radiotherapy. Clin Oncol 1984; 3: 571-96.

35. Hanssens M. Histopathology of malignant melanomas after ruthenium-106 irradiation. Read before Dutch Ophthalmopathol Soc Rotterdam, Netherlands, 1985.

36. Jensen OA. Malignant melanomas of the human uvea: 25-year follow-up of cases in Denmark, 1943-1952. Acta Ophthalmol 1982; 60: 161-82.

37. Kenneally CZ, Farber MG, Smith ME, Devineni R. In vitro melanoma cell growth after preenucleation radiation therapy. Arch Ophthalmol 1988; 106: 223-4.

38. Kincaid MC, Folberg R, Torczynski E, Zakov ZN, Shore JW, Liu SJ, Planchard TA, Weingeist TA. Complications after proton beam therapy for uveal malignant melanoma. Ophthalmology 1988; 95: 982-91.

39. Kindy-Degman NA, Char DH, Castro JR, Kroll S, Stone RD, Quivey JM, Phillips TL, Irvine AR. Effect of various doses of radiation for uveal melanoma on regression, visual acuity, complications and survival. Am J Ophthalmol 1989; 107: 114-22.

40. Kreissig I, Rohrbach JM. Bestrahlung des Auges vor Enukleation wegen Aderhautmelarom? Fortschr Ophthalmol 1988; 85: 196-9.

41. Lawton AW. Protom beam therapy for uveal melanoma. Ophthalmology 1989; 96: 138-9.

42. Lee WR. Pseudomelanomas after conservative management of uveal melanoma. Eye 1987; 1: 668-75.

43. Linstadt D, Char DH, Castro JR, Phillips TL, Quivey JM, Reimers M, Hannigan J, Collier JM. Vision following helium ion radiotherapy of uveal melanoma: a Northern California oncology group study. Int J Rad Oncol Biol Phys 1988; 15: 347-52.

44. Lobo PA, Liebner EJ, Chao EJ-H, Kanji AM. Radiotherapy in the management of malignant melanoma. Int $\mathrm{J}$ Rad Oncol Biol Phys 1981; 7: 21-6.

45. Lommatzsch PK. Results after $\beta$-irradiation $\left({ }^{106} \mathrm{Ru} /{ }^{106} \mathrm{Rh}\right)$ of choroidal melanomas: 20 years' experience. Brit J Ophthalmol 1986; 70: 844-51.

46. Lommatzsch PK, Kirsch $\mathrm{IH} .{ }^{106} \mathrm{Ru} /{ }^{106} \mathrm{Rh}$ plaque radiotherapy for malignant melanoma of the choroid. Doc Ophthalmol 1988; 68: 225-38.

47. Malaise EP, Chavaudra N, Charbit A, Tubiana M. Relationship between the growth rate of human metastases, survival and pathological type. Europ J Cancer 1974; 10: 451-9.
48. Manschot WA, van Peperzeel HA. Choroidal melanoma. Enucleation or observation? A new approach. Arch Ophthalmol 1980; 103: 71-7.

49. Manschot WA. The natural history of uveal melanoma and its therapeutic consequences. Doc Ophthalmol 1980; 50: $83-98$.

50. Manschot WA. Therapeutic options in uveal melanoma Correspondence. Am J Ophthalmol 1985; 99: 615-6.

51. Manschot WA, van Strik R. Is irradiation a justifiable treatment of choroidal melanoma? Analysis of published results. Brit J Ophthalmol 1987; 71: 348-52.

52. Manschot WA, van Strik R. Aderhautmelanom: Analyse publizierter Therapie-resultate. Fortschr Ophthalmol 1987; 84: 183-6.

53. Manschot WA, van Strik R. Bestrahlung von Aderhautmelanomen: verantwortbare Therapie oder ein medizinisches Experiment? Klin Mbl Augenheilk 1988; 192: 582-5.

54. Manschot WA, van Strik R. Is radiation a justifiable treatment of choroidal melanoma? Correspondence. Brit J Ophthalmol 1988; 72: 319-20.

55. Manschot WA. Choroidal melanoma after 1526 Gy ruthenium irradiation. Read before Verhoef Soc/Europ Ophthalmopathol Soc Philadelphia, 1986.

56. Manschot WA. Choroidal melanoma after 1377 Gy ruthenium irradiation. Read before German Ophthalmopathol Soc Essen, 1986.

57. McFaul PA, Morgan G. Histopathological changes in malignant melanomas of the choroid after cobalt plaque therapy. Brit J Ophthalmol 1977; 61: 221-8.

58. Pardee AB. Principles of cancer biology: biochemistry and cell biology. In: De Vita Jr VT, Hellman S, Rosenberg SA (editors). Cancer-principles and practice of oncology. Philadelphia, Lippincott, 1985, 2nd ed pp 3-22.

59. van Peperzeel H. Radiation therapy: before or after enućleation. Doc Ophthalmol 1980; 50: 71-3.

60. van Peperzeel HA. Treatment of retinoblastoma and choroidal melanoma. A Multidisciplinary approach. Int Ophthalmol 1985; 7: 255-8.

61. Pimm MV, Baldwin RW. Immunology and immunotherapy of experimental and clinical metastases. In: Baldwin RW (editor). Secondary spread of cancer. London, Acad. Press, 1978, pp 163-209.

62. Puck TT, Marcus PI. Action of X-rays on mammelian cells. J Exp Med 1956; 103: 653-66.

63. Rousseau A, Boudreault G, Deschenes J. Malignant melanoma radiation treatment prior to enucleation. In: Henkind $\mathrm{P}$ (editor). Acta XXIV Int Congr Ophthalmol. Philadelphia. Lippincott 1983, pp 983-7.

64. Sahel JA, Pesavento R, Frederick AR, Albert DM. Melanoma arising de novo over a 16-months period. Arch Ophthalmol 1988; 106: 381-5.

65. Schmitt H. Malignes Melanom der Aderhaut nach BetaBestrahlung. Read before German Ophthalmopathol Soc Erlangen, 1985.

66. Seddon JM, Gragoudas ES, Albert DM. Ciliary body and 
choroidal melanomas treated by proton beam irradiation. Arch Ophthalmol 1983; 101: 1402-8.

67. Seddom JM, Gragoudas ES, Egan KM, Glynn RJ, Howard S, Fante RG, Albert DM. Relative survival rates after alternative therapies for uveal melanoma. Ophthalmology 1990; 97: 769-77.

68. Seddon JM, Gragoudas ES, Polivogianis L, Hsieh C-C, Egan KM, Goitein M, Verhey L, Munzenrider J, Austin/ Seymour M, Urie M. Visual outcome after proton beam irradiation of uveal melanoma. Ophthalmology 1986; 93: 666-74.

69. Shields JA. Counseling the patient with a posterior uveal melanoma. Am J Ophthalmol 1988; 106: 88-91.

70. Shields CL, Shields JA, Karlsson U, Markoe AM, Brady LW. Reasons for enucleation after plaque radiotherapy for posterior uveal melanoma. Clinical findings. Ophthalmology 1989; 96: 919-24.

71. Shields CL, Shields JA, Karlsson U, Menduke H, Brady LW. Enucleation after plaque radiotherapy for posterior uveal melanoma. Histopathologic findings. Ophthalmology 1990; 97: 1665-70.

72. Stallard HB. Malignant melanoma of the choroid treated with radioactive applicators. Trans Ophthalmol Soc UK 1959; 79: 373-92.

73. Straatsma BR, Fine SL, Early JD, Hawkins BS, Diener-
West M, McLaughlin JA. Enucleation versus plaque irradiation for choroidal melanoma. Ophthalmology 1988; 95: 1000-4.

74. Thompson LH, Suit HD. Proliferation kinetics of X-irradiated mouse L-cells studied with time-lapse photography. II. Int J Radiat Biol 1969; 15: 347-62.

75. Trott KR, von Lieven H, Kummermehr J, Skopal D, Lukacs S, Braun-Falko O, Kellerer AM. The radiosensitivity of malignant melanomas. Part II: Clinical studies. Int J Rad Oncol Biol Phys 1981; 7: 15-20.

76. Zimmerman LE, McLean IW, Foster WD. Does enucleation of an eye containing a malignant melanoma prevent or accelerate the dissemination of tumour cells? Brit J Ophthalmol 1978; 62: 420-5.

77. Zinn KM, Stein-Pokorny K, Jakobiec FA, Friedman AH, Gragoudas ES, Ritch R. Proton beam irradiated epitheloid cell melanoma of the ciliary body. Ophthalmology $1981 ; 88$ : 1315-21.

Address for offprints:

W.A. Manschot,

Institute of Pathology, Erasmus University,

Postbox 1738, 3000 DR, Rotterdam,

The Netherlands 